Silke Heising • Lothar Richter • Wolfgang Ludwig Bernhard Schink

\title{
Chlorobium ferrooxidans sp. nov., a phototrophic green sulfur bacterium that oxidizes ferrous iron in coculture with a "Geospirillum" sp. strain
}

\begin{abstract}
A green phototrophic bacterium was enriched with ferrous iron as sole electron donor and was isolated in defined coculture with a spirilloid chemoheterotrophic bacterium. The coculture oxidized ferrous iron to ferric iron with stoichiometric formation of cell mass from carbon dioxide. Sulfide, thiosulfate, or elemental sulfur was not used as electron donor in the light. Hydrogen or acetate in the presence of ferrous iron increased the cell yield of the phototrophic partner, and hydrogen could also be used as sole electron source. Complexed ferric iron was slowly reduced to ferrous iron in the dark, with hydrogen as electron source. Similar to Chlorobium limicola, the phototrophic bacterium contained bacteriochlorophyll $c$ and chlorobactene as photosynthetic pigments, and also resembled representatives of this species morphologically. On the basis of 16S rRNA sequence comparisons, this organism clusters with Chlorobium, Prosthecochloris, and Pelodictyon species within the green sulfur bacteria phylum. Since the phototrophic partner in the coculture KoFox is only moderately related to the other members of the cluster, it is proposed as a new species, Chlorobium ferrooxidans. The chemoheterotrophic partner bacterium, strain KoFum, was isolated in pure culture with fumarate as sole substrate. The strain was identified as a member of the $\varepsilon$-subclass of the Proteobacteria closely related to "Geospirillum arsenophilum" on the basis of physiological properties and $16 \mathrm{~S}$ rRNA sequence comparison. The "Geospirillum" strain was present in the coculture only in low numbers. It fermented fumarate, aspartate, malate, or pyruvate to acetate, succinate, and carbon dioxide, and could reduce nitrate to
\end{abstract}

S. Heising $\cdot$ B. Schink $(\square)$

Fakultät für Biologie, Universität Konstanz, Postfach 5560,

D-78457 Konstanz, Germany

e-mail: bernhard.schink@uni-konstanz.de

Tel.: +49-7531-882140, Fax: +49-7531-882966

L. Richter · W. Ludwig

Lehrstuhl für Mikrobiologie, Technische Universität München, Arcisstraße 16, D-80290 München, Germany dinitrogen gas. It was not involved in ferrous iron oxidation but possibly provided a thus far unidentified growth factor to the phototrophic partner.

Key words Iron metabolism - Green phototrophic bacteria $\cdot$ Chlorobium ferrooxidans $\cdot$ Geospirillum . Phototrophic iron oxidation - 16S rRNA sequence analysis

\section{Introduction}

Iron is the fourth most important element in the Earth's crust, making up approximately $5 \%$ of the total crust mass (Ehrlich 1990). In biological systems, the redox change between the $\mathrm{Fe}(\mathrm{II})$ and the $\mathrm{Fe}$ (III) state is of utmost importance in redox reactions, especially in heme-containing proteins, iron-sulfur proteins, etc. (Neilands 1974). The redox change between $\mathrm{Fe}(\mathrm{II})$ and $\mathrm{Fe}(\mathrm{III})$ also plays an important role in redox processes in oxygen-limited environments such as sediments or water-logged soils. The redox potential of the $\mathrm{Fe}(\mathrm{II}) / \mathrm{Fe}$ (III) transition depends strongly on the prevailing $\mathrm{pH}$ : under strongly acidic conditions, the transition from $\mathrm{Fe}^{2+}$ to $\mathrm{Fe}^{3+}$ occurs at $E_{\mathrm{h}}=+0.77 \mathrm{~V}$, whereas at $\mathrm{pH} 7.0$ the transition occurs mainly between $\mathrm{FeCO}_{3}$ and $\mathrm{Fe}(\mathrm{OH})_{3}$, at $E_{\mathrm{h}}=+0.1-+0.2 \mathrm{~V}$ (Stumm and Morgan 1981; Widdel et al. 1993). This comparably low redox potential caused us to check whether also anoxygenic phototrophic bacteria could oxidize ferrous iron to ferric iron compounds with concomitant reduction of $\mathrm{CO}_{2}$ to cell material. Enrichment cultures have led to the isolation of several pure cultures of anoxygenic purple bacteria (Widdel et al. 1993), and some of these cultures have subsequently been described in more detail (Ehrenreich and Widdel 1994; Heising and Schink 1998). All isolated strains of ferrous iron oxidizers were Proteobacteria belonging either to the Chromatiaceae or to the non-sulfur purple bacteria. However, oxidation of ferrous iron to ferric iron should also be possible with the light reaction system of green phototrophs since the reaction centers of these bacteria accept electrons at a potential of $+0.3 \mathrm{~V}$ (Gottschalk 1985). 
In the present communication, we describe a novel green phototrophic bacterium related to Chlorobium, Prosthecochloris, and Pelodictyon species that oxidizes ferrous iron to ferric iron in coculture with a fermenting bacterium closely related to "Geospirillum arsenophilum".

\section{Materials and methods}

\section{Sources of organisms}

Enrichments for new cultures of anaerobic ferrous-iron-oxidizing bacteria were started with surface sediment samples from freshwater creeks and ditches close to Konstanz and Oldenburg (Germany). The binary mixed culture of strain KoFox and strain KoFum was obtained from a ditch close to the building of the Faculty of Biology, University of Konstanz (Germany). Chlorobium limicola $\mathrm{f}$. thiosulfatophilum strain 6230 (DSM 249) and Chlorobium vibrioforme strain $6030\left(\mathrm{DSM} 260^{\mathrm{T}}\right)$ were from our own culture collection (collection N. Pfennig, Konstanz, Germany).

Media and growth conditions

All strains were cultivated in a sulfide-free mineral medium designed for green sulfur bacteria (Trüper and Pfennig 1991) that was buffered with $30 \mathrm{mM}$ bicarbonate and contained $1 \mathrm{mM}$ sulfate as sulfur source. Vitamins were added from a stock solution (Pfennig 1978). Substrates were added from sterile, neutralized stock solutions. Ferrous iron was added to a final concentration of $8 \mathrm{mM}$ from a $0.8 \mathrm{M} \mathrm{FeSO}_{4}$ solution that was prepared and filter-sterilized under $\mathrm{N}_{2}$ gas and kept under $\mathrm{N}_{2}$ at $4^{\circ} \mathrm{C}$. Reaction of ferrous iron with bicarbonate led to the formation of a white precipitate of siderite $\left(\mathrm{FeCO}_{3}\right)$. The $\mathrm{pH}$ was adjusted to 6.5 unless indicated otherwise.

Ferrous sulfide was prepared by precipitation of $0.2 \mathrm{M} \mathrm{Na}_{2} \mathrm{~S}$ solution in $10 \mathrm{mM} \mathrm{NaOH}$ with an equal volume of $0.2 \mathrm{M} \mathrm{FeSO}_{4}$ in $10 \mathrm{mM} \mathrm{HCl}$ under $\mathrm{N}_{2}$ atmosphere. The precipitate was washed twice with sulfide-free mineral medium (Ehrenreich and Widdel 1994). Amorphous ferric hydroxide $\mathrm{Fe}(\mathrm{OH})_{3}$ was prepared by slow neutralization of $0.4 \mathrm{M} \mathrm{FeCl}_{3}$ with $0.5 \mathrm{M} \mathrm{NaOH}$. The precipitate was washed three times with distilled water to make a final suspension of approximately $0.4 \mathrm{M} \mathrm{Fe}(\mathrm{OH})_{3}$ (Lovley and Phillips 1986). $\mathrm{Fe}(\mathrm{III})$ citrate was prepared as a $0.2 \mathrm{M}$ stock solution from brown $\mathrm{Fe}(\mathrm{III})$ citrate monohydrate.

Bacteria were grown in 50-ml screw-capped bottles filled with liquid medium to the top. Utilization of $\mathrm{H}_{2}$ was tested in rubbersealed serum bottles with an $\mathrm{H}_{2} / \mathrm{CO}_{2}(80: 20$, v/v) headspace. Utilization of substrates was checked in $22-\mathrm{ml}$ screw-capped tubes. Cultures were incubated at $18^{\circ} \mathrm{C}$ at a distance of approximately 40 $\mathrm{cm}$ from a $40-\mathrm{W}$ bulb (equivalent to $14 \mathrm{~W} \cdot \mathrm{m}^{-2}$ ). For enrichment cultures, the conditions were varied with respect to $\mathrm{pH}(\mathrm{pH} 6.5$, 6.8 , and 7.3), various trace element solutions, and light intensity $\left(3-14 \mathrm{~W} \cdot \mathrm{m}^{-2}\right)$. Enrichment cultures were incubated behind infrared filters that excluded light at wavelengths $<740 \mathrm{~nm}$ (Göttinger Farbfilter, Göttingen, Germany). Formation of orange-brown precipitates indicated ferrous iron oxidation. Bacteria were purified from enrichment cultures in deep-agar dilution series (Pfennig 1978). $\mathrm{FeSO}_{4}$ was added as a sterile solution to the agar before the liquid medium was added in order to allow homogeneous distribution of $\mathrm{FeCO}_{3}$ through the entire medium. Culture purity was checked at regular intervals by phase-contrast microscopy after growth in mineral medium or in complex media (AC medium, diluted 1:10; Difco, Detroit, Mich., USA).

In vivo absorption spectra were taken in cell suspensions mixed with $5 \mathrm{~g}$ sucrose per $3 \mathrm{ml}$ culture fluid to avoid excessive light scattering (Pfennig and Trüper 1991). Spectra were taken with a Shimadzu UV-300 spectrophotometer (Shimadzu, Kyoto, Japan) in end-on position. Cells grown with ferrous iron were washed twice with $10 \mathrm{mM}$ EDTA in $50 \mathrm{mM}$ Tris- $\mathrm{HCl}(\mathrm{pH} 7.0)$ before sucrose was added.

For extraction of pheophytenes formed from bacteriochlorophylls, culture volumes of $10 \mathrm{ml}$ were centrifuged $(20 \mathrm{~min}$ at $3,000 \times g$ ) and resuspended in $1 \mathrm{ml}$ distilled water. After addition of $9 \mathrm{ml}$ of $0.1 \mathrm{M}$ citric acid in methanol, the mixture was shaken and incubated at $4{ }^{\circ} \mathrm{C}$ for $30 \mathrm{~min}$. After centrifugation $(20 \mathrm{~min}$ at $3,000 \times g$ ), the supernatant contained pheophytenes that were analyzed by spectrophotometry (Kontron, Zurich, Switzerland). An absorption maximum at $667.5 \mathrm{~nm}$ was characteristic of bacteriochlorophyll $c$, a maximum at $657.5 \mathrm{~nm}$ of bacteriochlorophyll $d$ (N. Pfennig, Konstanz, Germany, personal communication).

Carotenes were characterized by thin-layer chromatography and absorption spectra after extraction with a methanol/acetone $(2: 7, \mathrm{v} / \mathrm{v})$ mixture (Schmidt 1971).

\section{Analysis of $16 \mathrm{~S}$ rRNA sequences}

16S-rRNA-encoding DNA fragments were amplified and sequenced as described earlier (Springer et al. 1992). In the case of the phototrophic strain KoFox, which could only be grown in coculture with strain KoFum, the identity of the determined sequence was verified by in situ cell hybridization with fluorescent-specific probes (CY3- or fluorescein-labeled; MWG-BioTech, Ebersberg, Germany) that targeted terminal regions of the 16S rRNA. Standard procedures (Manz et al. 1992; Amann 1995) were applied for in situ hybridization and detection. The sequence data have been deposited at the EMBL database under accession nos. Y18254 for strain KoFum and Y18253 for the phototrophic strain of KoFox. The new 16S rRNA sequences were fitted into an alignment of approximately 16,000 homologous full or partial primary structures available in public databases (Ludwig 1995) using the respective automated tools of the ARB software package (Ludwig and Strunk 1997). Distance matrix, maximum parsimony, and maximum likelihood methods were applied for tree construction as implemented in the ARB software package. Different datasets varying with respect to the outgroup reference organisms (sequences) included and to the alignment positions were analyzed.

\section{Assay of redox balances}

Ten replicate 50-ml culture bottles with mineral medium containing $8 \mathrm{mM} \mathrm{FeSO}_{4}$ as sole electron source were inoculated with 2.5 $\mathrm{ml}$ of an outgrown defined coculture. Two bottles were assayed at the beginning, two control bottles were incubated in the dark, and these and the other six bottles were assayed at the end of the oxidation process after 35 days. The content of each culture bottle was transferred under nitrogen gas into larger glass vials containing $5 \mathrm{ml} \mathrm{37 \%} \mathrm{HCl}$ and was incubated at $100^{\circ} \mathrm{C}$ for $10 \mathrm{~min}$ to dissolve all ferric hydroxides. After centrifugation $(20 \mathrm{~min}$ at $3,000 \times g)$, samples were taken for determination of ferrous iron, ferric iron, and protein content (Lowry et al. 1951). Bacterial biomass was calculated using the formula $\left\langle\mathrm{C}_{4} \mathrm{H}_{7} \mathrm{O}_{3}\right\rangle$ (Biebl and Pfennig 1978) and was assumed to be composed of $50 \%$ protein.

Growth curves were recorded in a similar manner with three replicate cultures in 250-ml bottles sealed with butyl rubber septa and containing $200 \mathrm{ml}$ medium under an atmosphere of $\mathrm{N}_{2} / \mathrm{CO}_{2}$ $(80: 20, v / v)$. Samples for determination of ferrous iron, ferric iron, and protein content were taken with syringes at intervals of 4-5 days after intensive mixing of the bottle contents and were assayed as described above.

\section{Analytical methods}

For analysis of iron salts, $5 \mathrm{ml}$ of precipitate-free culture fluid was removed from $50-\mathrm{ml}$ culture bottles and was replaced with $5 \mathrm{ml}$ $37 \% \mathrm{HCl}$ to dissolve all iron precipitates. Ferrous iron was quantified by the ferrozine method (Stookey 1970); total iron was quantified by the same method after reduction with hydroxylamine. The 
difference between the ferrous iron and total iron concentrations was taken as the ferric iron concentration (Stookey 1970). Sulfide was quantified colorimetrically according to Cline (1969). Acetate was assayed by gas chromatography (Platen and Schink 1987).

Chemicals

All chemicals were of analytical-grade purity and were acquired from Alfa Products (Karlsruhe), Boehringer (Mannheim), Fluka (Neu-Ulm), Merck (Darmstadt), Riedel de Haen (Seelze), and Serva (Heidelberg), all in Germany. Gases at purity standard 5.0 were supplied by Sauerstoffwerke (Friedrichshafen, Germany).

\section{Results}

\section{Enrichment of iron-oxidizing bacteria}

For enrichment of novel iron-oxidizing phototrophic bacteria, 50-ml screw-capped bottles with mineral medium containing $8 \mathrm{mM} \mathrm{FeSO}_{4}$ as electron source (precipitated as $\mathrm{FeCO}_{3}$ ) and inocula (approximately $2-3 \mathrm{ml}$ each) from sediments of various ditches were incubated at $18^{\circ} \mathrm{C}$ in dim light behind filters that excluded light of $<740 \mathrm{~nm}$ wavelength. After 4-6 weeks of incubation, the white siderite precipitates had turned brownish in 47 of more than 90 different enrichment cultures. Enrichments were most successful at pH 6.8 and low light intensity (3-6 W per $\mathrm{m}^{2}$ ); enrichments at $\mathrm{pH} 6.5$ or 7.3, or at higher light intensities $\left(10 \mathrm{~W}\right.$ per $\left.\mathrm{m}^{2}\right)$ yielded active cultures in only $10-20 \%$ of all assays. The choice of the trace element solution [SL 10 or SL 12; see Pfennig and Trüper (1991)] had no influence on the outcome of the enrichments. Cultures were transferred five to ten times in the same medium at $\mathrm{pH}$ 6.8, with $8 \mathrm{mM} \mathrm{FeSO}_{4}$ as sole electron source and trace element solution SL 10. Oxidation of ferrous iron was nearly complete in the subcultures after 2-3 weeks, and in most cultures a greenish color was observed in the culture liquid. In vivo absorption spectra exhibited a maximum at $756 \mathrm{~nm}$, indicating that green phototrophic bacteria with bacteriochlorophyll $c$ were present. Microscopy with UV light (390-420 nm excitation wavelength) gave no indication of red fluorescence as is typical of chlorophyll- $a$-containing cyanobacteria.

In deep-agar dilutions, the green phototrophic bacteria could not be purified with $8 \mathrm{mM} \mathrm{FeSO}_{4}$ alone or in the additional presence of $1 \mathrm{mM}$ acetate, 2 or $4 \mathrm{mM}$ ascorbate, or $80 \%$ hydrogen in the head space. Dark green colonies grew only in the first dilution tube and always contained several morphological types of bacteria. In alternative dilution series with $4 \mathrm{mM}$ sulfide as electron source, colonies were formed as far up as the third dilution tubes and were composed of green centers with white satellites, sometimes also with red components. Liquid cultures inoculated with cell material from these colonies oxidized ferrous iron within 3-4 weeks and contained at least three types of bacteria: short rods, motile vibrioid cells, and a few stalked cells reminiscent of Rhodomicrobium vannielii (Widdel et al. 1993). In subsequent dilution series with $2 \mathrm{mM}$ sulfide and $0.5 \mathrm{mM} \mathrm{FeSO}$, the stalked cells could be outdiluted. However, the other two cell types could not be separated in dilution experiments with either sulfide at various concentrations $(0.5-2 \mathrm{mM})$ or hydrogen as additional electron source, and the same problem arose with five different enrichment cultures treated in the same manner. After growth in liquid medium with $8 \mathrm{mM} \mathrm{FeSO}_{4}$, an enrichment culture from a ditch close to the biology building at the University of Konstanz showed a ratio of short rods to vibrios of approximately 1,000:1; this culture was used for further purification studies. Nonetheless, this culture also did not yield a pure culture of the phototrophic bacterium in dilutions in liquid or in agar medium. Therefore, we first purified the contaminating vibrioid bacterium.

Purification and properties of the vibrioid partner bacterium

Since the morphology of the vibrioid partner bacterium suggested a relationship to Campylobacter sp., we tried to purify this bacterium with fumarate as sole substrate. Transfers into liquid medium with $5 \mathrm{mM}$ fumarate caused a dramatic increase of the vibrioid cells (over 90\%) as compared to the short rods, and in two subsequent agar dilution series starting from the phototrophic enrichment culture, the vibrioid bacterium (strain KoFum) was isolated in pure culture with fumarate as substrate.

Cells of strain KoFum were highly motile vibriod rods, $0.5 \times 2-4 \mu \mathrm{m}$ in size, and often appeared in pairs or short chains (Fig. 1a). Cells were gram-negative upon staining (Bartholomew 1962) and KOH Gram typing (Gregersen 1978), carried one polar flagellum each, and were catalase-negative and oxidase-positive. The strain grew at $30^{\circ} \mathrm{C}$ with fumarate, with a doubling time of approximately $1 \mathrm{~h}$, and fermented fumarate, malate, or aspartate completely to succinate, acetate, and butyrate roughly in a 7:1:0.3 ratio. Pyruvate was fermented to acetate, hydrogen, and carbon dioxide. Formate, acetate, lactate, ethanol, glucose, fructose, xylose, and arabinose were not oxidized or fermented; sulfate, thiosulfate, or elemental sulfur were not reduced. Nitrate was reduced to dinitrogen gas with hydrogen, fumarate, or ferrous iron as electron donor, and ferric iron was reduced only slowly with hydrogen as electron donor (approximately $7 \%$ reduced after 3 weeks of incubation).

Characterization of the phototrophic partner in the coculture

The phototrophic partner bacterium could be purified easily in deep-agar dilution series with $8 \mathrm{mM} \mathrm{FeCO}_{3}$ in the presence of a background lawn of strain KoFum. In ferrous-irongrown liquid cultures, strain KoFum amounted to approximately $0.1 \%$ of the total bacterial community (Fig. 1b). Cells of the phototrophic bacterium, strain KoFox, were $0.5 \times 1 \mu \mathrm{m}$ in size and often appeared in pairs (Fig. 1b). Cells were immotile and gram-negative according to staining and $\mathrm{KOH}$ Gram typing. 
Fig. 1 Phase-contrast photomicrograph of strain KoFum and the coculture. a Strain KoFum grown with fumarate. $\mathbf{b}$ The binary mixed culture KoFox grown with ferrous carbonate. Arrow points at a cell of strain KoFum (bar $5 \mu \mathrm{m})$
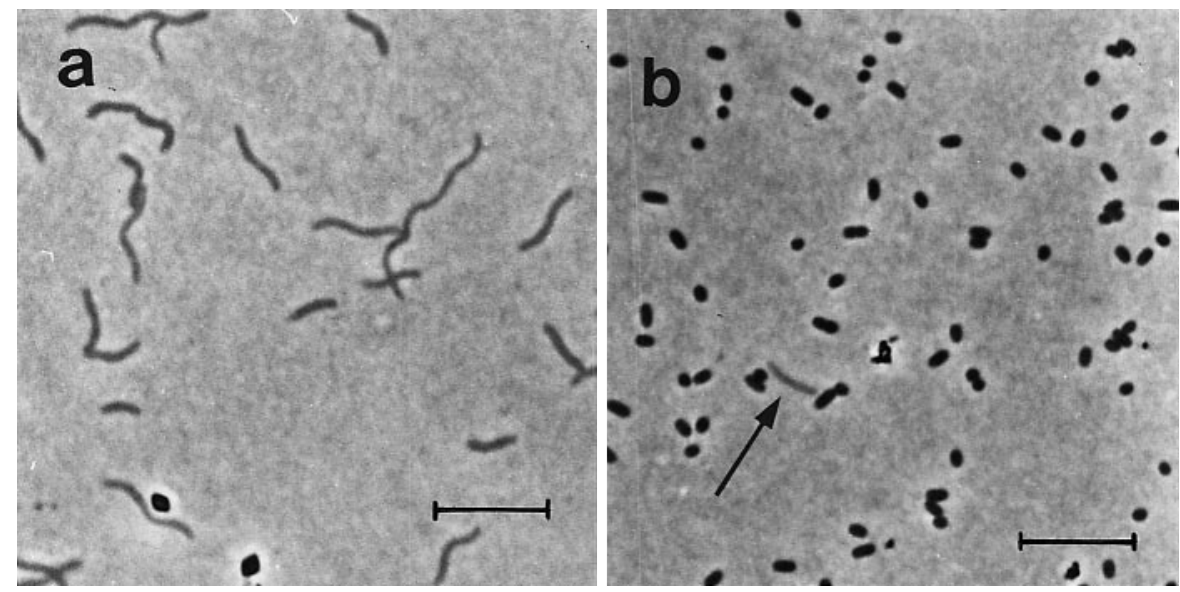

Growth with ferrous iron carbonate under optimal conditions was exponential, with a doubling time of 5.3 days $\left(\mu=0.132\right.$ days $\left.^{-1}\right)-$ however, often with extended lag phases of 5-10 days. The optimum temperature for growth was $22-25^{\circ} \mathrm{C}$; growth was possible at $18-30^{\circ} \mathrm{C}$. The $\mathrm{pH}$ range was 6.3-7.1, with an optimum at $\mathrm{pH}$ 6.5-6.7.

The stoichiometry of ferrous iron oxidation and cell mass formation is documented in Table 1. Oxidations were always nearly $100 \%$, with variations of $5-10 \%$. The measured growth yield was $7.5 \mathrm{~g}$ cell mass per mol ferrous iron oxidized, as expected from calculations using the cell mass formula $\left\langle\mathrm{C}_{4} \mathrm{H}_{7} \mathrm{O}_{3}\right\rangle$ (Table 1). No ferrous iron oxidation was found in the dark or in noninoculated cultures.

Absorption spectra were taken with suspensions of living cells of the coculture and were compared to spectra obtained with Chl. limicola f. thiosulfatophilum grown with $2 \mathrm{mM}$ sulfide. As shown in Fig. 2, the two absorption spectra were identical, with absorption maxima at wavelengths of 335, 457, and $756 \mathrm{~nm}$. The maximum at 457 $\mathrm{nm}$ is due to the carotenoid chlorobactene, the maximum at $756 \mathrm{~nm}$ to bacteriochlorophyll $c$ (Trüper and Pfennig 1991). The identity of bacteriochlorophyll $c$ was confirmed after extraction with methanol/citric acid. The ab- sorption spectrum exhibited a maximum at $668 \mathrm{~nm}$, which is typical of bacteriopheophytene.

Although Chl. limicola f. thiosulfatophilum resembled the phototrophic component of the coculture, it did not oxidize ferrous iron in our hands; nor did it do so after addition of strain KoFum. Ferrous iron oxidation was also not observed with Chl. vibrioforme.

In order to optimize the growth conditions for the coculture, further possible substrates were provided either alone or together with ferrous sulfate. No growth was observed with sulfide $(0.5-2 \mathrm{mM})$, thiosulfate $(5 \mathrm{mM})$, or elemental sulfur alone or in various combinations with each other. Sulfide added at a concentration of $1 \mathrm{mM}$ even inhibited growth with $\mathrm{H}_{2}$. Ferrous sulfide $(\mathrm{FeS})$ was oxidized very slowly in the course of incubation times of 2-3 months.

Oxidation of ferrous iron was accelerated by the presence of hydrogen, acetate, pyruvate, fumarate, cysteine, or thiosulfate (even though the latter was not used as sole electron donor); acetate and hydrogen specifically increased the number of the green bacteria in the coculture (Table 2). Nonetheless, we could not identify growth conditions that would allow growth and isolation of the phototrophic partner bacterium in pure culture; the following

Table 1 Growth and substrate oxidation balance of the binary mixed culture KoFox plus KoFum. FeSO 4 was added to all cultures to a final concentration of $8 \mathrm{mM}$

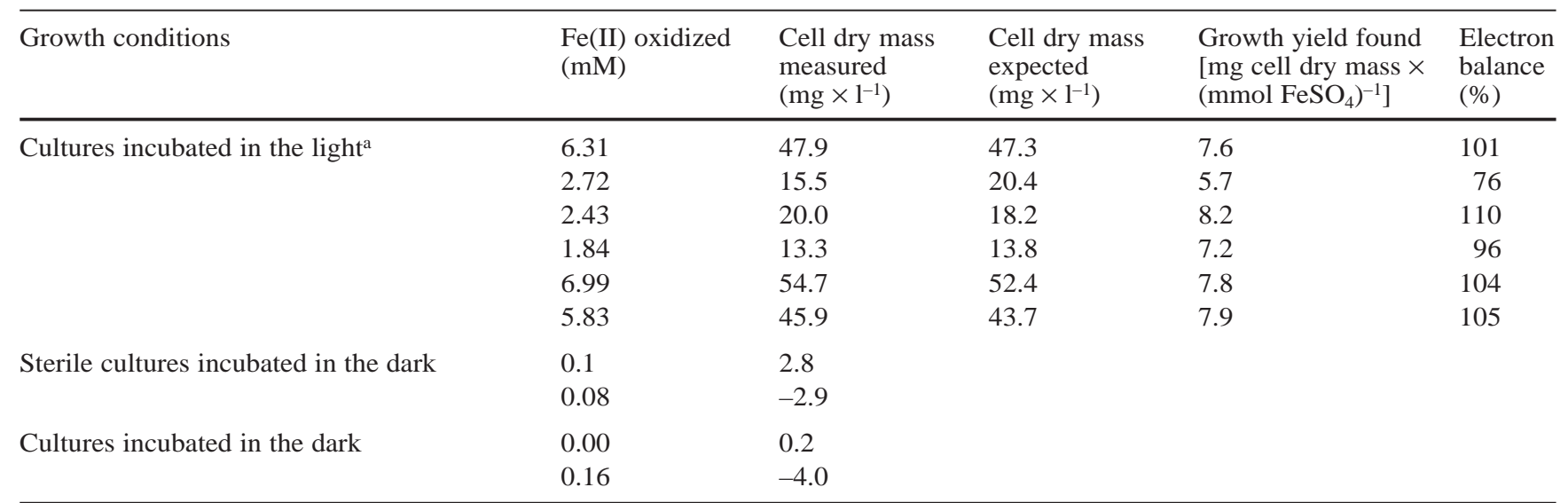

${ }^{\mathrm{a}}$ Results of six parallel experiments 


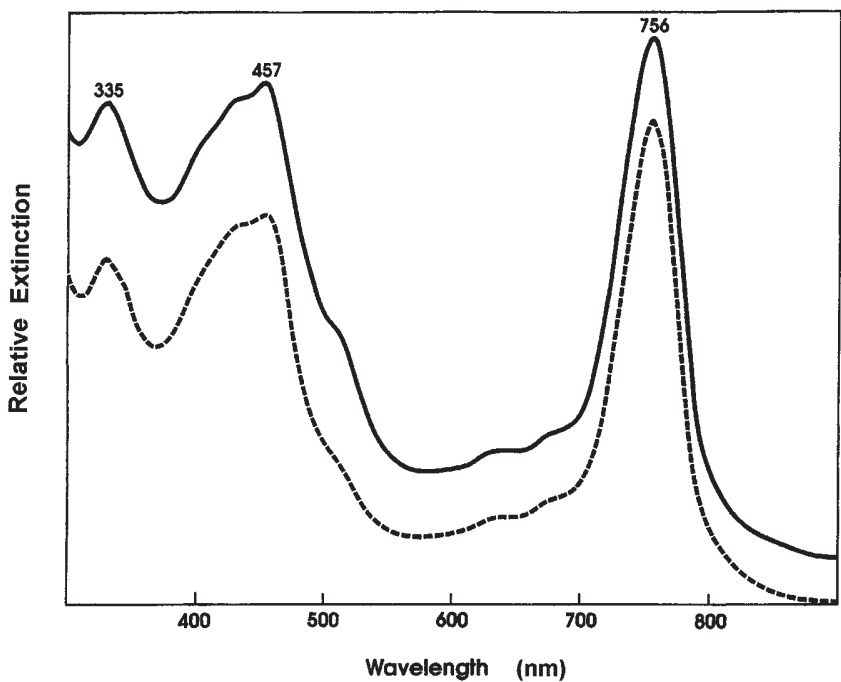

Fig. 2 Absorption spectra of living cells of the binary mixed culture (solid line) and Chlorobium limicola f. thiosulfatophilum (broken line). The mixed culture was grown with ferrous carbonate under a hydrogen/carbon dioxide atmosphere; Chl. limicola was grown with $2 \mathrm{mM}$ sulfide

additions to the medium were tried without success: yeast extract, prefermented yeast extract, sediment extract, or filter-sterilized spent medium of the coculture or of strain KoFum, both maintained under strictly anoxic conditions before application.

Reduction of ferric iron in the dark

The coculture was grown phototrophically with $\mathrm{FeCO}_{3}$. After incubation in the dark with hydrogen as electron donor, the formation of ferrous iron was examined, but no significant reduction of the previously produced ferric hydroxide was observed. However, from ferric nitrilotriacetate or ferric citrate, ferrous iron was produced at rates of up to $33 \mathrm{nmol} \mathrm{Fe}(\mathrm{II}) \times \min \times(\text { mg protein })^{-1}$, which is in the same range of electron transfer activity as observed during phototrophic growth with $\mathrm{FeCO}_{3}[24 \mathrm{nmol}$ $\mathrm{Fe}(\mathrm{II}) \times \min \times(\mathrm{mg} \text { protein })^{-1}$, as calculated from the growth rate and the growth yield]. This activity may at least partly be due to strain KoFum in the coculture.
Taxonomic assignment of the isolates by $16 \mathrm{~S}$ rRNA sequence analysis

Comparative 16S rRNA sequence analysis revealed a close relationship (99.4\% overall 16S rRNA sequence similarity) of the vibroid strain KoFum and of "Geospirillum arsenophilum" (to date still not validly described) (Ellis et al. 1997. These two strains cluster with other "Geospirillum" (Lonergan et al. 1996), "Dehalospirillum" (Scholz-Muramatsu et al. 1995), and Sulfurospirillum (Finster et al. 1997) species (Fig. 3). The corresponding sequence similarity values were in the range of 91.999.4\%, whereas similarities to the Campylobacter species of $86.3-88.6 \%$ indicate only a moderate relationship. Both phylogenetic groups are representatives of the $\varepsilon$-subclass of the Proteobacteria.

Modern standard techniques allow rRNA sequence determination for uncultured organisms from mixed cultures and complex environmental samples (Amann et al. 1995). However, specific probe design and in situ cell hybridization have to be performed in order to assign a sequence to a specific morphotype. Given that the phototrophic strain in KoFox can only be grown in coculture with strain KoFum, two specific oligonucleotide probes were designed that targeted regions close to the termini of the Chlorobium-type 16S rRNA sequence retrieved from the coculture (KoFox 173, 5'-CCGCTGCATCATCTGGTA-3', corresponding to $E$. coli $16 \mathrm{~S}$ rRNA positions 173-190; KoFox1240, 5'-TGCCCTCTGTAGCTACCA-3', corresponding to E. coli $16 \mathrm{~S}$ rRNA positions 1240-1257). After in situ hybridization of the coculture, the fluorescent hybridization signals of both probes could clearly be assigned only to the Chlorobium-like cells. This result corroborates that the determined Chlorobium-type sequence originated from strain KoFox. Furthermore, given that the probes have distant target sites on the rRNA molecule, the results also document that no chimeric sequence was amplified from the original coculture.

The Chlorobium-like partner in the coculture KoFox was shown indeed to be a representative of the green sulfur bacteria phylum and is related to Chlorobium (Woese et al. 1990; Wahlund et al. 1991; Figueras et al. 1997; Overmann and Tuschak 1997), Prosthecochloris (Overmann and Tuschak 1997), and Pelodictyon (Overmann and Tuschak 1997) species (Fig. 4). However, no close relationship was found to any strain (including the type

Table 2 Influence of various substrates on iron oxidation and on the composition of the binary mixed culture during growth in the light with ferrous sulfate. An anoxic medium without an additional reducing agent was used under an $\mathrm{N}_{2} / \mathrm{CO}_{2}$ atmosphere

\begin{tabular}{llll}
\hline $\begin{array}{l}\text { Cultures grown } \\
\text { with } 8 \mathrm{mM} \mathrm{FeSO}\end{array}$ plus: & $\begin{array}{l}\text { Acceleration of } \\
\text { iron oxidation }\end{array}$ & $\begin{array}{l}\text { Cell numbers of green } \\
\text { bacteria increased }\end{array}$ & $\begin{array}{l}\text { Cell numbers } \\
\text { of strain KoFum increased }\end{array}$ \\
\hline $\mathrm{H}_{2} / \mathrm{CO}_{2}$ & + & + & - \\
Acetate $(2 \mathrm{mM})$ & + & + & - \\
Pyruvate $(2 \mathrm{mM})$ & + & + & + \\
Fumarate $(5 \mathrm{mM})$ & + & + & + \\
$\mathrm{Cysteine}^{2}(2 \mathrm{mM})$ & + & - & - \\
$\mathrm{S}_{2} \mathrm{O}_{3}{ }^{2-}(2 \mathrm{mM})$ & + & - & - \\
\hline
\end{tabular}

a As compared to cultures grown with $8 \mathrm{mM} \mathrm{FeSO}_{4}$ as sole substrate 


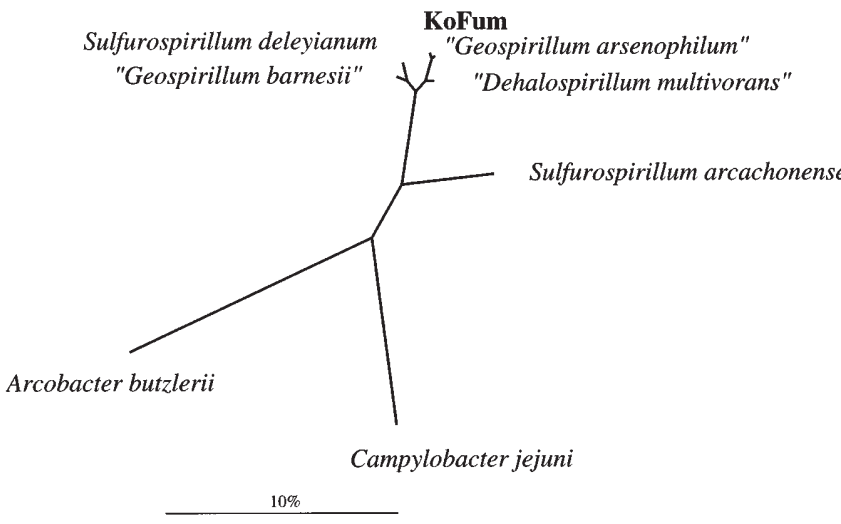

Fig. 3 16S-rRNA-based unrooted tree reflecting the phylogentic relationships of strain KoFum. The tree is based on the results of a maximum likelihood analysis of sequences from a selection of close and moderately related reference organisms of the $\varepsilon$-subclass of the Proteobacteria. The tree topology was evaluated by performing distance matrix and maximum parsimony analyses of all available small-subunit rRNA sequence data from representatives of the $\varepsilon$-subclass of the Proteobaceria and selected representatives of other major lines of descent or the full dataset. Almost complete sequences (comprising at least $90 \%$ of the gene in comparison with the corresponding Escherichia coli sequence) were used for the tree construction. Only sequence positions that share identical residues in at least $50 \%$ of all sequences from the "Geospirillum", "Dehalospirillum", and Sulfurospirillum cluster were included for the calculations (bar 10\% estimated sequence divergence)

strains) for which rRNA sequence data currently are available. Overall 16S rRNA sequence similarity values of $91.4-96.7 \%$ indicate that our strain represents a separate line of descent within a Chlorobium/Pelodictyon/Prosthecochloris cluster.

\section{Discussion}

Ferrous iron oxidation by a green phototrophic bacterium

Oxidation of ferrous iron by phototrophic bacteria is still a novel phenomenon that to date has been observed only with phototrophic purple sulfur or non-sulfur bacteria (Widdel et al. 1993; Ehrenreich and Widdel 1994; Heising and Schink 1998). Phototrophic oxidation of ferrous iron has been discussed in a broader perspective mainly with reference to its possible implications for our understanding of the early evolution of life on Earth. The question arose whether the banded iron formations are really indicative of the first appearance of oxygen in the atmosphere (Walker et al. 1983; Beukes and Klein 1992) due to an oxygenic two-step photosynthesis by cyanobacteria, for example, or whether these oxidized layers could also have been produced by anoxygenic phototrophs using only one light reaction (Widdel et al. 1993; Ehrenreich and Widdel 1994). Our finding that ferrous iron can also be oxidized by green anoxygenic phototrophic bacteria may add to further speculations on the question of how banded iron formations originated; since the green phototrophs represent a separate group within the domain Bacteria, this may indicate that

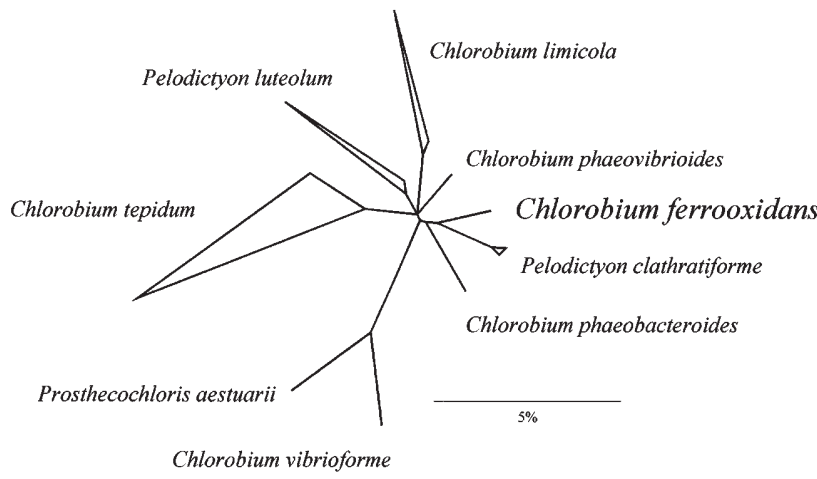

Fig. 4 16S-rRNA-based tree reflecting the phylogentic relationships of Chlorobium ferrooxidans, the phototrophic component of the coculture KoFox. The tree is based on the results of a maximum likelihood analysis of all available sequences from representatives of the green sulfur bacteria phylum and a selection of members of the Cytophaga/Flavobacterium/Bacteroides phylum. The tree topology was evaluated and corrected according to the results of distance matrix and maximum parsimony analyses of all available small-subunit rRNA sequence data from the green sulfur bacteria and Cytophaga/Flavobacterium/Bacteroides phyla and from selected representatives of other major lines of descent or the full dataset of the ARB sequence database (Ludwig and Strunk 1997). Multifurcations indicate that a common relative branching order was not significantly supported by application of the alternative treeing approaches. Almost complete sequences (comprising at least $90 \%$ of the gene in comparison with the homologous Escherichia coli sequence) were used for the tree construction. Only sequence positions that share identical residues in at least $50 \%$ of all sequences from the representatives of the green sulfur bacteria phylum were included for the calculations. The triangles indicate phylogenetic groups. The Chlorobium tepidum cluster comprises Chl. tepidum ATCC 49652 ${ }^{\mathrm{T}}$, Chl. limicola strains DSM 246, UdG 6038, UdG 6040, UdG 6041, UdG 6042, UdG 6043, UdG 6044, and UdG 6045, and Chlorobium vibrioforme strains DSM 263, UdG 6026, and UdG 6043. The Chlorobium limicola cluster comprises Chl. limicola $6330\left(\mathrm{DSM} 245^{\mathrm{T}}\right)$ and Chlorobium phaeobacteroides strains UdG 6046, UdG 6047, and UdG 6051. The Chlorobium phaeovibrioides branch comprises only Chl. phaeovibrioides strain $2631\left(\mathrm{DSM} 269^{\mathrm{T}}\right)$. The Pelodictyon clathratiforme cluster comprises Pld. clathratiforme GP and Pelodictyon phaeoclathratiforme BU-1 (DSM 5477 $)$. The Pelodictyon luteolum cluster comprises P. luteolum 2530 (DSM273 ${ }^{\mathrm{T}}$ ), Chl. vibrioforme 6132 (DSM 262), and Chl. phaeovibroides UdG 6035. The Prosthecochloris aestuarii cluster comprises Chl. vibrioforme DSM 260 and P. aestuarii SK 413 (DSM 271 $)$ (bar 5\% estimated sequence divergence)

phototrophic ferrous iron oxidation was a widespread metabolic capacity in an early phase of evolution.

On the basis of comparisons of the redox potential of the couples $\mathrm{FeOOH} / \mathrm{FeCO}_{3}$ and the acceptor redox potential of green phototrophs (Widdel et al. 1993; Gottschalk 1985), ferrous iron oxidation by green anoxygenic phototrophic bacteria was expected to be possible. However, growth of these bacteria is slow, and green phototrophs can be enriched with ferrous iron only at a comparably low temperature $\left(18^{\circ} \mathrm{C}\right)$. Incubation at higher temperatures $\left(20-25^{\circ} \mathrm{C}\right)$ selects for growth of Rhodomicrobium vannielii (Widdel et al. 1993; Heising and Schink 1998). The defined coculture characterized in the present study was substantially slower $\left(t_{\mathrm{d}}=5.3\right.$ days $)$ than the pure cultures of purple bacteria described previously (doubling times of 2-4.5 days; 
Ehrenreich and Widdel 1994). Thus, the green phototrophs would hardly have a chance of being enriched in conventional enrichment cultures with ferrous iron at higher temperatures, and this may explain why they have been overlooked in our earlier studies.

Oxidation of ferrous iron by the defined coculture was stoichiometrically coupled to biomass formation from $\mathrm{CO}_{2}$ according to the equation:

$17 \mathrm{FeCO}_{3}+29 \mathrm{H}_{2} \mathrm{O} \rightarrow 17 \mathrm{Fe}(\mathrm{OH})_{3}+\left\langle\mathrm{C}_{4} \mathrm{H}_{7} \mathrm{O}_{3}\right\rangle+13 \mathrm{CO}_{2}$.

Iron oxidation was nearly complete; a small amount of remnant ferrous iron (approximately $5 \%$ of the substrate provided) was probably not accessible to the bacteria, perhaps due to formation of mixed oxides, e.g., magnetite. Growth was exponential, although the free $\mathrm{Fe}^{2+}$ ion concentration in the medium in equilibrium with $\mathrm{FeCO}_{3}$ is only approximately $3 \mu \mathrm{M}$ (Ehrenreich and Widdel 1994). The green bacteria were obviously more efficient in the release of the insoluble ferric iron oxides than is $R$. vannielii, which encrusts itself in rusty layers that severely limit metabolic activity after growth with ferrous iron (Heising and Schink 1998). It has been postulated that the purple phototrophic strains L7 and SW2 transfer the electrons from ferrous iron by a carrier system across the periplasmic space to the reaction center in the cytoplasmic membrane (Ehrenreich and Widdel 1994), but this postulated electron carrier still awaits identification.

Compared to other green phototrophs, strain KoFox behaves atypically in not utilizing sulfide as sole electron source, but a thorough evaluation of the known strains of green phototrophs revealed that actually more such bacteria are sensitive to free sulfide (J. Overmann, Oldenburg, Germany, personal communication). Ferrous sulfide was utilized so slowly that this capacity can hardly be used as a reliable physiological criterion for taxonomic purposes.

The physiological importance of ferrous iron oxidation for our strain may be substantial since we could find only a few alternative electron sources that supported phototrophic growth of this strain. Whether the oxidized ferric iron hydroxides can act as electron acceptors for a respiratory metabolism in the dark still needs to be elucidated. We found ferric iron reduction only with chelated ion forms such as ferric citrate or ferric nitrilotriacetate. The ecological significance of these activities is questionable since chelated iron reacts unspecifically with many electron transfer systems. Due to this background, the reported iron reduction activities of Rhodobacter capsulatus (Dobbin et al. 1996) and of many heterotrophic iron reducers (Lovley 1993) also need to be critically revised because they have nearly exclusively been obtained with chelated ferric iron forms whose importance in natural environments is hard to assess.

Cooperation between the partners in the coculture

In spite of many efforts, we could not separate the green component of the coculture from its "Geospirillum"-like chemoheterotrophic partner organism. The number of the partner cells after growth with ferrous iron was so low that one cannot expect that these partners fulfilled any substantial function in energy generation comparable, for example, to that of the partners in syntrophic associations (Pfennig 1980; Schink 1997). Furthermore, the difference between the redox potentials of the $\mathrm{FeOOH} / \mathrm{FeCO}_{3}$ couple $(+200 \mathrm{mV})$ and that of the reaction center of the green phototrophs $(+300 \mathrm{mV})$ can hardly allow for a functional niche of a further bacterium in electron transfer between these two systems, and not even the supply of an ironchelating agent could be expected from such a partner due to its low number. Rather, we have to assume that the chemoheterotrophic partner provides some trace nutrient(s) to the phototroph that we are thus far unable to provide with our medium. Such relationships have been reported earlier, e.g., for the extremely low-light-adapted culture Chlorobium phaeobacteroides from the redox interface of the Black Sea (Overmann et al. 1992), or for fermenting defined cocultures that degrade resorcinol (Tschech and Schink 1985) or dipicolinic acid (Seyfried and Schink 1990). In all these cases, vibrioid partner bacteria similar to strain KoFum have been present in low numbers and have been essential for growth although their function in the coculture has never been resolved.

\section{Taxonomy of the two bacterial strains}

On the basis of its morphology, pattern of substrate utilization and product formation, and lack of acetate oxidation capacity, the chemoheterotrophic bacterium strain KoFum was assumed to be related to the genus Campylobacter, which together with the genera Arcobacter, Alvinella, "Dehalospirillum", "Geospirillum", Helicobacter, Wolinella, and Sulfurospirillum represents the $\varepsilon$-subclass of the Proteobacteria. The comparative analysis of its $16 \mathrm{~S}$ rRNA sequence data corroborated a moderate relationship to Campylobacter strains (Fig. 3); however, the closest relative is "Geospirillum arsenophilum", as indicated by $99.4 \%$ 16S rRNA sequence similarity. "Dehalospirillum", "Geospirillum", and Sulfurospirillum represent a phylogenetic sister group of Campylobacter.

The green component of the coculture was identified as a relative of a phylogenetic group comprising Chlorobium, Pelodictyon, and Prosthecochloris species. However, no close relative is known to date, and strain KoFox represents its own line of descent within this group. Based on comparison of $16 \mathrm{~S}$ rRNA sequence similarity data, it has been shown previously that the various strains grouped in species of the genus Chlorobium appear to be a heterogeneous collection of different organisms (Figueras et al. 1997; Overmann and Tuschak 1997). Subgroups containing strains of different Chlorobium species have been defined by Figueras et al. (1997). The majority of these clusters is also supported by analysis of the enlarged dataset available today. However, there is no significant evidence for a separation of brown (Chl. phaeobacteroides and Chl. phaeovibroides) and green (Chl. limicola, Chl. tepidum, and Chl. vibrioforme) species as pos- 
tulated by Figueras et al. (1997). These authors have found a clear correlation of 16S-rRNA-based phylogeny and the content of green and brown bacterial chlorophylls. According to their analyses, a clear separation of greenand brown-pigmented chlorobia is supported by the rRNA data. The comparative analysis of the now-enlarged dataset of 16S rRNA sequences does not support such a clear separation (Fig. 4); similar results have been obtained recently by Overmann and Tuschak (1997). Furthermore, not only strains of different Chlorobium species appear to be phylogenetically intermixed; a similar situation has also been found for Prosthecochloris and Pelodictyon strains (Overmann and Tuschak 1997).

Nonetheless, strain KoFox differs from all Chlorobium strains in its obvious lack of sulfide oxidation since species of the genus Chlorobium by definition oxidize sulfide, sulfur, and often thiosulfate. Utilization of acetate is typical of Chlorobium species (Pfennig and Trüper 1971). These differences are supported by (moderate) overall 16S rRNA sequence similarities of 91.4-96.3\%.

Here, the new species Chlorobium ferrooxidans is proposed, with the phototrophic component of the culture KoFox as the type strain.

Formal description of Chlorobium ferroxidans sp. nov.

Chlorobium ferrooxidans (sp. nov.) fer.ro.ox'i.dans; ferrum L.n.n., iron; oxidans M.L.adj., oxidizing; ferrooxidans, ironoxidizing.

Short, rod-shaped cells, $0.5 \times 1.0-1.5 \mu \mathrm{m}$ in size, with rounded ends, single or in pairs. Nonmotile, gram-negative, nonsporeforming.

Strictly anaerobic phototroph. Oxidizes ferrous iron provided in the medium as ferrous carbonate to ferric iron hydroxides. Hydrogen or acetate enhance ferrous-iron-dependent growth, and hydrogen is also used as sole electron source. Sulfide not oxidized. No assimilation of organic substrates other than acetate. Grows in freshwater medium with ferrous iron as sole electron source, in defined coculture with a "Geospirillum"-like bacterium, strain KoFum.

Selective enrichment from freshwater ditches and ponds at $18^{\circ} \mathrm{C}$ under dim light behind light filters that exclude light of $740 \mathrm{~nm}$ wavelength.

$\mathrm{pH}$ range, 6.3-7.1; $\mathrm{pH}$ optimum, 6.5-6.7. Temperature range, $18-30^{\circ} \mathrm{C}$; temperature optimum, $22-25^{\circ} \mathrm{C}$.

Habitat: anoxic sediments of shallow freshwater ditches.

Type strain: KoFox, deposited with the Deutsche Sammlung von Mikroorganismen und Zellkulturen (Braunschweig, Germany).

Acknowledgements The authors are greatly indebted to N. Pfennig, J. Overmann, and F. Widdel for helpful advice regarding the cultivation and taxonomy of green phototrophs and the chemistry of iron transformation. R. Warthmann contributed data on iron reduction by the coculture. The technical assistance of I. Pomper and M. Kultzen is acknowledged. This study was supported by the Deutsche Forschungsgemeinschaft (Bonn-Bad Godesberg, Germany) within the framework of "Sonderforschungsbereich 248: Stoffhaushalt des Bodensees".

\section{References}

Amann R (1995) In situ identification of microorganisms by whole cell hybridization with rRNA-targeted nucleic acid probes. In: Akkermans ADL, Van Elsas JD, De Bruijn FJ (eds) Molecular microbial ecology manual. Kluwer, Dordrecht, pp 1-15

Amann R, Ludwig W, Schleifer KH (1995) Phylogentic identification and in situ detection of individual microbial cells without cultivation. Microbiol Rev 59:143-169

Bartholomew JW (1962) Variables influencing results and the precise definition of steps in Gram staining as a means of standardizing the results obtained. Stain Technol 37:139-155

Beukes NJ, Klein C (1992) Models for iron-formation deposition. In: Schopf J, Klein C (eds) The proterozoic biosphere. Cambridge University Press, Cambridge, pp 147-151

Biebl H, Pfennig N (1978) Growth yields of green sulfur bacteria in mixed cultures with sulfur and sulfate reducing bacteria. Arch Microbiol 117:9-16

Cline JD (1969) Spectrophotometric determination of hydrogen sulfide in natural waters. Limnol Oceanogr 14:454-458

Dobbin PS, Warren LH, Cook NJ, McEwan AG, Powell AK, Richardson DJ (1996) Dissimilatory iron(III) reduction by Rhodobacter capsulatus. Microbiology 142:765-774

Ehrenreich A, Widdel F (1994) Anaerobic oxidation of ferrous iron by purple bacteria, a new type of phototrophic metabolism. Appl Environ Microbiol 60:4517-4526

Ehrlich HL (1990) Geomicrobiology. Dekker, New York, pp 283-346

Ellis DJ, et al (1997) Geospirillum gen. nov. in the family Campylobacteraceae. EBI Databases, Hinxton, Cambridge

Figueras JB, Garcia-Gil LJ, Abella CA (1997) Phylogeny of the genus Chlorobium based on 16S rDNA sequence. FEMS Microbiol Lett 152:31-36

Finster K, Liesack W, Tindall BJ (1997) Sulfurospirillum arcachonense sp. nov., a new microaerophilic sulfur-reducing bacterium. Int J Syst Bacteriol 47:1212-1217

Gottschalk G (1985) Bacterial metabolism, 2nd edn. Springer, Berlin Heidelberg New York

Gregersen T (1978) Rapid method for distinction of Gram-negative from Gram-positive bacteria. Eur J Appl Microbiol Biotechnol 5:123-127

Heising S, Schink B (1998) Phototrophic oxidation of ferrous iron by a Rhodomicrobium vannielii strain. Microbiology 144 : 2260-2269

Lonergan DJ, Jenter HL, Coates JD, Phillips EJ, Schmidt TM, Lovley DR (1996) Phylogenetic analysis of dissimilatory Fe(III)-reducing bacteria. J Bacteriol 187:2402-2408

Lovley DR (1993) Dissimilatory metal reduction. Annu Rev Microbiol 47:263-290

Lovley DR, Phillips EJP (1986) Organic matter mineralization with reduction of ferric iron in anaerobic sediments. Appl Environ Microbiol 51:683-689

Lowry OH, Rosebrough NJ, Farr AL, Randall RJ (1951) Protein measurement with the Folin phenol reagent. J Biol Chem 193:265-275

Ludwig W (1995) Sequence databases. In: Akkermans ADL, Van Elsas JD, De Bruijn FJ (eds) Molecular microbial ecology manual. Kluwer, Dordrecht, pp 1-22

Ludwig W, Strunk O (1997) ARB: a software environment for sequence data. http://www.mikro.biologie.tu-muenchen.de/pub/ ARB/documentation/arb.ps/url

Manz W, Amann R, Ludwig W, Wagner M, Schleifer KH (1992) Phylogenetic oligonucleotide probes for the major subclasses of Proteobacteria: problems and solutions. Syst Appl Microbiol 15:593-600

Neilands JB (1974) Iron and its role in microbial physiology. In: Neilands JB (ed) Microbial iron metabolism. Academic Press, New York, pp 3-34

Overmann J, Tuschak C (1997) Phylogeny and molecular fingerprinting of green sulfur bacteria. Arch Microbiol 167:302-309 
Overmann J, Cypionka H, Pfennig N (1992) An extremely low light adapted phototrophic sulfur bacterium from the Black Sea. Limnol Oceanogr 37:150-155

Pfennig N (1978) Rhodocyclus purpureus, gen. nov. and sp. nov., a ring-shaped vitamin $\mathrm{B}_{12}$-requiring member of the family Rhodospirillaceae. Int J Syst Bacteriol 28:283-288

Pfennig N (1980) Syntrophic mixed cultures and symbiotic consortia with phototrophic bacteria: a review. In: Gottschalk G, Pfennig N, Werner H (eds) Anaerobes and anaerobic infections. Fischer, Stuttgart, pp 127-131

Pfennig N, Trüper HG (1971) Type and neotype strains of the species of phototrophic bacteria maintained in pure culture. Int J Syst Bacteriol 21:19-24

Pfennig N, Trüper HG (1991) The family Chromatiaceae. In: Balows A, Trüper HG, Dworkin M, Schleifer KH (eds) The prokaryotes, 2nd edn. Springer, Berlin Heidelberg New York, pp 3200-3221

Platen H, Schink B (1987) Methanogenic degradation of acetone by an enrichment culture. Arch Microbiol 149:136-141

Schink B (1997) Energetics of syntrophic cooperations in methanogenic degradation. Microbiol Mol Biol Rev 61:262-280

Schmidt K (1971) Carotenoids of purple nonsulfur bacteria. Arch Microbiol 77:231-238

Scholz-Muramatsu H, Neumann A, Messmer M, Moore E, Diekert G (1995) Isolation and characterization of Dehalospirillum multivorans gen. nov., sp. nov., a tetrachlorethene-utilizing, strictly anaerobic bacterium. Arch Microbiol 163:48-56

Seyfried B, Schink B (1990) Fermentative degradation of dipicolinic acid (pyridine-2,6-dicarboxylic acid) by a defined coculture of strictly anaerobic bacteria. Biodegradation 1:1-7
Springer N, Ludwig W, Drozanski V, Amann R, Schleifer KH (1992) The phylogenetic status of Sarcobium lyticum, an obligate intracellular parasite of small amoebae. FEMS Microbiol Lett 96:199-202

Stookey LL (1970) Ferrozine - a new spectrophotometric reagent for iron. Anal Chem 42:779-781

Stumm W, Morgan JJ (1981) Aquatic chemistry. Wiley, New York

Trüper HG, Pfennig N (1991) The family Chlorobiaceae. In: Balows A, Trüper HG, Harder W, Schleifer KH (eds) The prokaryotes, 2nd edn. Springer, Berlin Heidelberg New York, pp 3583-3592

Tschech A, Schink B (1985) Fermentative degradation of resorcinol and resorcylic acids. Arch Microbiol 143:52-59

Wahlund TM, Woese CR, Castenholz RW, Madigan MT (1991) A thermophilic green sulfur bacterium from New Zealand hot springs, Chlorobium tepidum sp. nov. Arch Microbiol 156: 81-90

Walker JCG, Klein M, Schidlowski JW, Schopf JW, Stevenson DJ (1983) Environmental evolution of the archean-early proterozoic biosphere. In: Schopf JW (ed) Earth's earliest biosphere. Princeton University Press, Princeton, pp 260-290

Widdel F, Schnell S, Heising S, Ehrenreich A, Assmus B, Schink B (1993) Ferrous iron oxidation by anoxygenic phototrophic bacteria. Nature 362:834-836

Woese CR, Mandelco L, Yang D, Gherna R, Madigan MT (1990) The case for relationship of the flavobacteria and their relatives to the green sulfur bacteria. Syst Appl Microbiol 13:258-262 